\title{
MUSCARINIC RECEPTOR BINDING AND OXIDATIVE ENZYME ACTIVITIES IN THE ADULT RAT SUPERIOR CERVICAL GANGLION: EFFECTS OF 6-HYDROXYDOPAMINE AND NERVE GROWTH FACTOR ${ }^{1}$
}

\author{
ANTHONY M. DOMBROWSKI, ANN A. JERKINS, AND FREDERICK C. KAUFFMAN ${ }^{2}$ \\ Department of Pharmacology and Experimental Therapeutics, University of Maryland School of Medicine, \\ Baltimore, Maryland 21201
}

Received December 13, 1982; Revised March 17, 1983; Accepted April 28, 1983

\begin{abstract}
Administration of 6-hydroxydopamine to adult rats results in changes in the superior cervical ganglion similar to those noted after axotomy; namely, a decrease in muscarinic receptor binding and increases in activities of the oxidative enzymes of the pentose phosphate pathway. These changes were either prevented or attenuated markedly by the systemic administration of nerve growth factor. Administration of nerve growth factor alone did not significantly increase $N$ methylscopolamine binding in the ganglion or reduce the activities of the oxidative enzymes. Explants of the ganglion maintained in serum-free medium over a period of 3 days demonstrated increases in oxidative enzyme activity and a decrease in $N$-methylscopolamine binding. Addition of $20 \mathrm{nM}$ nerve growth factor to the culture medium prevented the decline in $N$-methylscopolamine binding in ganglion explants. The increases in oxidative enzyme activities were unaltered. Addition of high amounts of nerve growth factor, $200 \mathrm{nM}$, resulted in a significant increase in tyrosine hydroxylase activity but no further increase in $N$-methylscopolamine binding in ganglion explants. Glucocorticoids added to the culture medium did not affect the muscarinic binding or enzyme activities. Thus, decreases in muscarinic binding activity which occur in the superior cervical ganglion after axotomy or 6-hydroxydopamine treatment may be explained by a loss of nerve growth factor supplied to the ganglion. Increases in the oxidative enzymes of the pentose phosphate pathway that occur in the ganglion after axonal injury appear to involve additional factors.
\end{abstract}

The capacity of nerve growth factor (NGF) to stimulate neurite fiber outgrowth from sensory and sympathetic neurons and clones of rat pheochromocytoma cells (Levi-Montalcini and Angeletti, 1968; Thoenen and Barde, 1980) has spurred the investigation of the mechanism of action of this hormone-like peptide in the hope of better understanding the regulation of neuronal growth and regeneration. The possibility that NGF or related substances influence biochemical changes in nerve cell bodies during the retrograde response to axonal injury is suggested by a number of studies using the

\footnotetext{
${ }^{1}$ Gratitude is expressed to Mrs. Margaret Shimkaveg for her excellent help in preparing the manuscript and to Drs. David Burt and Martin Larrabee for their critical comments. This work was supported in part by United States Public Health Service Grant HD-16596 and the United States Army Medical Research Development Command.

${ }^{2}$ To whom correspondence should be addressed, at Department of Pharmacology and Experimental Therapeutics, University of Maryland School of Medicine, 660 W. Redwood Street, Baltimore, MD 21201.
}

superior cervical ganglion as a model. Upiake of both exogenous and endogenous NGF at nerve terminals and retrograde transport to the superior cervical ganglion has been established (Hendry et al., 1974a, b; Johnson et al., 1978; Palmatier et al., 1982). Although sympathetic neurons may not have an absolute requirement for this peptide after 3 weeks of postnatal life (Hendry, 1975), NGF reaching the ganglion via retrograde transport has been strongly implicated in the induction of tyrosine hydroxylase and the production of a general hypertrophic response (Hendry, 1977). Increased utilization of glucose, as indexed by 2-deoxyglucose uptake, is one of the earliest biochemical changes noted in axotomized neural tissue, and this change is prevented by inhibition of retrograde axoplasmic flow (Singer et al., 1982).

In addition to affecting the biochemical properties of the ganglion, NGF also has significant actions on the response of this tissue to neurotransmitters. Halstead and Larrabee (1972) demonstrated that a single dose of NGF antiserum caused a significant reduction in the 
postganglionic response to acetylcholine in superior cervical ganglia of neonatal mice as early as $48 \mathrm{hr}$ after injection. Using guinea pig superior cervical ganglia, Purves (1975) and Purves and Nja (1976) demonstrated that the depression of the fast EPSP amplitude following surgical postganglionic axotomy was reversed with locally applied NGF. Axotomy or treatment with antiNGF antibodies was also shown to produce a loss of synapses and presynaptic fibers in rat and guinea pig superior cervical ganglia (Matthews and Nelson, 1975; Nja and Purves, 1978). Thus, changes in ganglionic transmission that occur with axotomy may be mediated through decreases in the number of cholinergic receptors as well as the loss of presynaptic elements.

The present series of experiments was performed to determine whether selected biochemical changes brought about by axonal injury are influenced by NGF. Since surgical axotomy produces a fall in muscarinic ligand binding that correlates temporally with increases in 6phosphogluconate dehydrogenase (EC 1.1.1.44) (Sinicropi et al., 1979) and glucose-6-phosphate dehydrogenase activity (Harkonen and Kauffman, 1974), we exam ined the influence of axonal injury and NGF on the activities of the oxidative enzymes of the pentose phosphate pathway and muscarinic receptor content in the superior cervical ganglion. 6-Hydroxydopamine treatment of adult rats was used to destroy nerve terminals of postganglionic fibers and to reduce retrograde transport of NGF to the ganglion in vivo (Johnson et al., 1979). Biochemical alterations produced by chemical axotomy with 6-hydroxydopamine in vivo were compared in the presence and absence of NGF administered systemically. The direct influence of NGF on muscarinic binding and enzyme activities was also examined on explants of adult superior cervical ganglion maintained in serum-free medium. The results suggest that whereas amounts of muscarinic binding in the ganglion are influenced by NGF, regulation of the activities of the two pentose phosphate pathway enzymes may involve additional factors.

\section{Materials and Methods}

Preparation of tissue. Adult male Sprague-Dawley rats (Charles River Breeding Laboratory, Wilmington, MA) weighing 125 to $200 \mathrm{gm}$ were used in all experiments. Animals were anesthetized with chloral hydrate $(400 \mathrm{mg} /$ $\mathrm{kg}$ ) and superior cervical ganglia were decentralized as described previously (Burt, 1978). Explant cultures of superior cervical ganglia were prepared in serum-free media according to the method reported earlier (Dombrowski and Kauffman, 1981) except that cultures were maintained in plastic culture wells $(16 \mathrm{~mm}$ diameter, clusters of 24; Costar, Cambridge, MA) and 7 S NGF was used in all experiments. Only the four central sections from each ganglion were explanted for culture.

For biochemical analyses, animals were killed by decapitation and the ganglia were removed, desheathed in ice-cold saline, frozen on dry ice, and stored at $-80^{\circ} \mathrm{C}$. Explants of ganglia maintained in vitro, except those used for microscopic histochemistry, were rinsed in 50 $\mathrm{ml}$ of ice-cold saline, blotted, and frozen and stored at $-80^{\circ} \mathrm{C}$. Freeze-thawing had no effect on any of the biochemical determinations.
6-Hydroxydopamine and NGF treatment. The solutions of 6 -hydroxydopamine $(30 \mathrm{mg} / \mathrm{ml})$ were prepared in cold saline containing $0.2 \mathrm{mg} / \mathrm{ml}$ of ascorbate directly before use. Injections of the drug $(100 \mathrm{mg} / \mathrm{kg})$ were either intraperitoneal or intravenous. The two routes of administration are equally effective in reducing retrograde transport of NGF (Johnson et al., 1979).

The $7 \mathrm{~S}$ complex of NGF was used in all studies and was prepared according to the method of Burton et al. (1978). The $7 \mathrm{~S}$ complex, which eluted as a single welldefined peak (peak II) from the Sephadex G-100 column was pooled, concentrated using Millipore CX-30 ultrafiltration units, and stored in small aliquots at $-80^{\circ} \mathrm{C}$. Typically, 350 to $400 \mu \mathrm{g}$ of protein were obtained in this fraction per mouse. Analysis of the pooled fraction by isoelectric focusing (O'Farrell, 1975) in $6.8 \%$ polyacrylamide gels having a $\mathrm{pH} 4$ to 8.5 gradient indicated the presence of only three bands that were identical to the subunits of the $7 \mathrm{~S}$ complex (Burton et al., 1978). Injections of NGF (2.5 to $3.8 \mathrm{mg} / \mathrm{kg}$, s.c.) were in $0.025 \mathrm{M}$ sodium phosphate, $\mathrm{pH} 6.8$.

Biochemical analysis. Whole ganglia used for the determination of enzyme and binding activities were homogenized in $75 \mu \mathrm{l}$ of $0.04 \mathrm{M}$ Tris- $\mathrm{HCl}, \mathrm{pH} \mathrm{7.4,} \mathrm{containing}$ $100 \mu \mathrm{M} \mathrm{NADP}{ }^{+}$. Explants (2) used for enzyme determinations were homogenized in $30 \mu \mathrm{l}$ of the same medium. Explants (4) used for binding assays were homogenized in $45 \mu \mathrm{l}$ of $0.02 \mathrm{M}$ sodium phosphate, $\mathrm{pH}$ 7.4.

Tyrosine hydroxylase activity was measured using the assay system described by Coyle (1972). L-[side chain$2,3-{ }^{3} \mathrm{H}_{1}$ ] Tyrosine (Amersham; $15 \mathrm{Ci} / \mathrm{mmol}$ ) was purified as described except the effluent from the alumina column was acidified with an equal volume of $2.0 \mathrm{~N} \mathrm{HCl}$, lyophilized at $-40^{\circ} \mathrm{C}$, resuspended in ethanol (about $0.14 \mathrm{mCi}$ / $\mu \mathrm{l}$ ), and stored at $-80^{\circ} \mathrm{C}$. Unlabeled L-tyrosine was standardized spectrophotometrically $(\epsilon 279.5 \mathrm{~nm}=1340$ in 0.1 $\mathrm{N} \mathrm{HCl}$ ). A 5- $\mu \mathrm{l}$ aliquot of the explant homogenate or a 7$\mu \mathrm{l}$ aliquot of whole ganglion homogenate was added to 20 or $43 \mu \mathrm{l}$, respectively, of $0.05 \mathrm{M}$ Tris- $\mathrm{HCl}, \mathrm{pH} 7.4$, containing $0.02 \%$ Triton $\mathrm{X}$. Incubations for tyrosine hydroxylase were started with the addition of an equal volume of reagent A containing: $0.04 \mathrm{M} \mathrm{KH}_{2} \mathrm{PO}_{4}$ adjusted to $\mathrm{pH} 5.5,100 \mu \mathrm{M}$ L-tyrosine, $0.5 \mu \mathrm{g} / \mu \mathrm{l}$ of catalase, $40 \mu \mathrm{l} /$ $\mathrm{ml}$ of dihydropteridine reductase, $1.0 \mathrm{mM} \mathrm{NADH}^{+}, 1 \mathrm{mM}$ 6-methyltetrahydropteridine, $1 \mathrm{~mm} \mathrm{FeSO}$, and 25,000 cpm $\left[{ }^{3} \mathrm{H}\right]$ tyrosine $/ \mu \mathrm{l}$. Reactions were carried out at $37^{\circ} \mathrm{C}$, terminated with $500 \mu \mathrm{l}$ of $0.4 \mathrm{M} \mathrm{HClO}_{4}$ containing $6 \mu \mathrm{g}$ of 3,4-dihydroxyphenylalanine (L-DOPA), and centrifuged at $3000 \times g$ for $5 \mathrm{~min}$. A $500-\mu \mathrm{l}$ aliquot was added to $6 \mathrm{ml}$ of reagent $\mathrm{B}$ containing: $1.0 \mathrm{M}$ Tris, $0.04 \mathrm{M}$ $\mathrm{KH}_{2} \mathrm{PO}_{4}, 1 \%$ EDTA, and $15 \mathrm{mg}$ of sodium bisulfite adjusted to $\mathrm{pH} 8.6$ with $\mathrm{HCl}$. Sodium bisulfite $(15 \mathrm{mg})$ was added to the reagent directly before use. This mixture was immediately applied to $200 \mathrm{mg}$ of acidified alumina in a column rinsed with $6 \mathrm{ml}$ of reagent $B$. After washing twice with $10 \mathrm{ml}$ of deionized water, the adsorbed L-DOPA was eluted with $3 \mathrm{ml}$ of $0.3 \mathrm{~N} \mathrm{HCl}$. Hydromix ( $15 \mathrm{ml}$; Yorktown Research, Hackensack, NJ) was added to the samples which were then assayed for radioactivity in a liquid scintillation counter with a counting efficiency of about $33 \%$. The assay was linear with time for at least $30 \mathrm{~min}$ with protein ranging up to $0.75 \mu \mathrm{g} / \mu \mathrm{l}$ of reaction mixture. The blanks contained less 
than $1 \%$ of the total radioactivity present and enzyme activities were typically 5 to 6 times the assay blanks.

Muscarinic receptor binding was measured with $N$ $\left[{ }^{3} \mathrm{H}\right]$ methylscopolamine (New England Nuclear, $83.5 \mathrm{Ci} /$ $\mathrm{mmol}$ ) as the ligand (Birdsall et al., 1978). A 7- $\mu$ l aliquot of the ganglion or explant homogenate was added to 45 $\mu \mathrm{l}$ of $0.02 \mathrm{M}$ sodium phosphate, $\mathrm{pH} 7.4$, containing 1.5 nM $N-\left[{ }^{3} \mathrm{H}\right]$ methylscopolamine and incubated at $37^{\circ} \mathrm{C}$ for $30 \mathrm{~min}$. Nonspecific binding was determined in the presence of $1.0 \mu \mathrm{M}$ atropine. The reaction mixture tubes were rinsed three times with $2.5 \mathrm{ml}$ of ice-cold saline onto 2.4$\mathrm{cm}$ Whatman GF/B filters at negative pressure. The filters were washed with three $2.5-\mathrm{ml}$ rinses of cold saline, drained of excess fluid, and counted in $4 \mathrm{ml}$ of Hydromix. For homogenates of whole ganglia, triplicate measurements of total and duplicate measurements of nonspecific binding were made. Duplicate measurements of both total and nonspecific binding were done for homogenates of pooled explants. Total binding in control samples represented less than $5 \%$ of the available radioactivity. In assays of whole ganglia, the total binding was 3 times the nonspecific background, whereas in assays of pooled explants, the total binding was twice the nonspecific binding. Doubling the concentration of ligand did not increase specific binding. A preliminary study of $N-\left[{ }^{3} \mathrm{H}\right]$ methylscopolamine binding in ganglion homogenates indicated a dissociation constant of $0.27 \mathrm{nM}$, which is comparable to the value reported for this ligand in brain homogenates and slices (Birdsall et al., 1978; Wamsley et al., 1980). Counting efficiency averaged $44 \%$.

Glucose-6-phosphate dehydrogenase and 6-phosphogluconate dehydrogenase were assayed as described previously (Harkonen and Kauffman, 1974) using $1 \mu \mathrm{l}$ of either ganglion or explant homogenates and $50 \mu \mathrm{l}$ of the appropriate reagent. Protein was determined by the method of Lowry et al (1951).

Enzyme histochemistry. Glucose-6-phosphate and 6phosphogluconate dehydrogenase activities in fresh frozen sections of ganglion explants were localized by the reduction of nitroblue tetrazolium at alkaline $\mathrm{pH}$ using the method described previously by Harkonen and Kauffman (1974) for whole ganglia. The explants were mounted on a cryostat chuck in brain paste stained with blue dextran and frozen in an acetone-dry ice bath. The $10-\mu \mathrm{m}$ transverse sections were incubated in reaction mixtures buffered with $0.05 \mathrm{M}$ 2-amino-2-methyl-1-propanol hydrochloride, $\mathrm{pH} 8.8$.

Reagents. 6-Hydroxydopamine as the $\mathrm{HCl}$ or $\mathrm{HBr}$ salt and 6-methyltetrahydropteridine were obtained from Sigma Chemical Co., St. Louis, MO. Catalase was purchased from Boehringer Mannheim. $N-\left[{ }^{3} \mathrm{H}\right]$ Methylscopolamine was a gift from the laboratory of Dr. M. Kuhar, and the dihydropteridine reductase was generously provided by Dr. J. Coyle.

\section{Results}

Effects of 6-hydroxydopamine and NGF on muscarinic receptor concentration and enzyme activities in vivo. The treatment of adult male rats with three consecutive daily injections of 6 -hydroxydopamine $(100 \mathrm{mg} / \mathrm{kg})$ resulted in a $60 \%$ decrease in the specific binding of $N-\left[{ }^{3} \mathrm{H}\right]$ methylscopolamine in the superior cervical ganglion at $24 \mathrm{hr}$ after the last injection (Table I). Increases in the specific activities of both glucose-6-phosphate dehydrogenase and 6-phosphogluconate dehydrogenase of about $28 \%$ also occurred over the same time period (Table II). These results are comparable to those noted after surgical transection of the postganglionic fibers of the superior cervical ganglion (Sinicropi et al., 1979).

The administration of three daily injections of NGF $(3.8 \mathrm{mg} / \mathrm{kg})$ along with 6 -hydroxydopamine diminished the decrease in muscarinic binding seen with 6-hydroxydopamine alone (Table I). Furthermore, the induction of glucose-6-phosphate dehydrogenase and 6-phosphogluconate dehydrogenase seen with chemical axotomy was prevented by NGF (Table II); however, activities of both oxidative enzymes of the pentose phosphate pathway in the superior cervical ganglion remained unchanged following treatment with NGF alone. The activity of glucose-6-phosphate dehydrogenase was significantly lower in ganglia of animals that had received 6-hydroxydopa-

\section{TABLE I}

The effect of 6-hydroxydopamine and NGF on $\mathrm{N}-\left[{ }^{3} \mathrm{H}\right]$ methylscopolamine binding and protein in vivo

Values are the mean \pm SEM of the number of ganglia indicated in parentheses. Experimental animals were treated for 3 consecutive days with either 6-hydroxydopamine, NGF, or both. Control animals were injected with saline containing ascorbate, phosphate buffer, or both, respectively. The Student's $t$ test was used for comparisons.

\begin{tabular}{lcc}
\hline \multicolumn{1}{c}{ Treatment } & $\begin{array}{c}\text { Specific } \\
N-\left[^{3} \mathrm{H}\right]- \\
\text { Methylscopolamine } \\
\text { Binding }\end{array}$ & Protein \\
& fmol/mg protein & $\mu g /$ ganglion \\
& $171 \pm 10(25)$ & $102 \pm 4(29)$ \\
Control & $65.2 \pm 7.1(10)^{a}$ & $121 \pm 9(13)^{b}$ \\
6-Hydroxydopamine, 100 & \\
mg/kg & $112 \pm 10(11)^{c, d}$ & $98.2 \pm 5.8(11)$ \\
6-Hydroxydopamine, 100 & \\
mg/kg, and NGF, 3.8 & \\
$\mathrm{mg} / \mathrm{kg}$ & \\
$\mathrm{NGF}, 2.5 \mathrm{mg} / \mathrm{kg}$ & \\
\hline${ }^{a} p<0.001$, compared to controls. \\
${ }^{b} p<0.05$, compared to controls. \\
${ }^{c} p<0.01$, compared to controls. \\
${ }^{d} p<0.01$, compared to 6-hydroxydopamine treated.
\end{tabular}

TABLE II

The effect of 6-hydroxydopamine and NGF on the specific activities of glucose-6-phosphate dehydrngenase and 6-phosphogluconate dehydrogenase

Values are the mean \pm SEM of the number of ganglia indicated in parentheses. Experimental animals were-treated for 3 consecutive days with either 6-hydroxydopamine, NGF, or both. Controls were injected with vehicle alone. Analysis of variance was used to compare differences between groups.

\begin{tabular}{lcc}
\hline \multicolumn{1}{c}{ Treatment } & $\begin{array}{c}\text { Glucose-6-phosphate } \\
\text { Dehydrogenase }\end{array}$ & $\begin{array}{c}\text { 6-Phosphogluconate } \\
\text { Dehydrogenase }\end{array}$ \\
\hline & \multicolumn{1}{c}{$\mu$ mol/mg protein $/ \mathrm{hr}$} \\
Control & $2.32 \pm 0.17(19)$ & $2.62 \pm 0.13(17)$ \\
6-Hydroxydopamine, & $2.97 \pm 0.15(10)^{a}$ & $3.48 \pm 0.22(13)^{b}$ \\
$\quad 100 \mathrm{mg} / \mathrm{kg}$ & & \\
6-Hydroxydopamine, & $2.41 \pm 0.19(11)^{c}$ & $2.83 \pm 0.17(6)$ \\
$\quad 100 \mathrm{mg} / \mathrm{kg}$, and & & \\
NGF, $2.5 \mathrm{mg} / \mathrm{kg}$ & & \\
$\mathrm{NGF}, 2.5 \mathrm{mg} / \mathrm{kg}$ & $2.37 \pm 0.14(6)$ & $2.92 \pm 0.18(6)$ \\
\hline
\end{tabular}

\footnotetext{
${ }^{a} p=0.014$ compared to controls.

${ }^{b} p=0.002$ compared to controls.

${ }^{c} p=0.04$ compared to 6 -hydroxydopamine.
} 


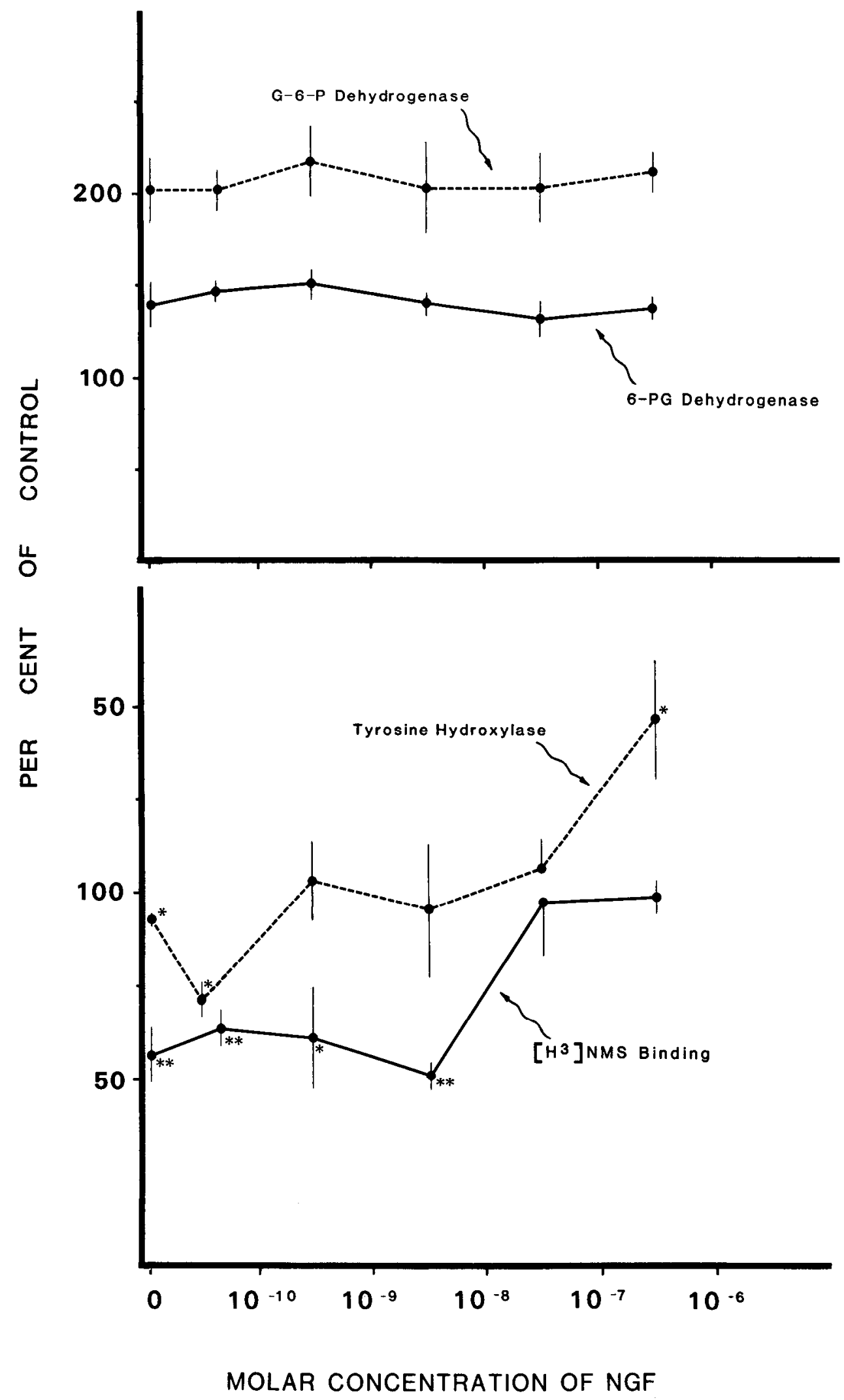

Figure 1. The effect of NGF on enzyme activities and muscarinic ligand binding in explants of the superior cervical ganglion. Each point represents the mean \pm SEM of three to five paired samples. Explants taken from the same ganglia as those cultured under the various conditions served as the matched controls. The tissue was cultured for 3 days. All values for glucose-6phosphate $(G-6-P)$ and 6-phosphogluconate $(6-P G)$ dehydrogenase activity represent statistically significant changes from fresh control values noted in tissue. A matched pair $t$ test was used for comparison of difference from control values. Data obtained in enzyme and binding 
mine plus NFG than in ganglia from animals treated with 6-hydroxydopamine alone. Administration of NGF to animals treated with 6-hydroxydopamine also resulted in a marginally significant $(p=0.06)$ decrease in the activity of 6-phosphogluconate dehydrogenase.

Although there was a tendency $(0.05<p<0.1)$ for NGF to reduce the increase in protein produced by 6 hydroxydopamine (Table I), the difference in muscarinic binding and enzyme activities between the two groups cannot be explained by the slight differences in ganglionic protein. Administration of three daily injections of a dose of NGF $(2.5 \mathrm{mg} / \mathrm{kg})$ alone had no effect on muscarinic binding in the superior cervical ganglion.

Effects of NGF on muscarinic receptors and enzyme activities in vitro. Changes in muscarinic receptor binding noted in vivo also occurred in explants of the superior cervical ganglion maintained in a serum-free culture medium for 3 days (Fig. 1). In the absence of added NGF or in the presence of NGF at concentrations less than 10 $\mathrm{nM}$, muscarinic receptor binding decreased to values that averaged only $57 \%$ of that present prior to culture. Addition of higher concentrations of NGF (20 and $200 \mathrm{mM}$ ) prevented the decline in muscarinic binding in cultured tissue; i.e., muscarinic binding in these explants was the same as that observed in fresh explants. NGF had no effect on the total protein content of explants maintained in vitro (Table III).

Activities of glucose-6-phosphate dehydrogenase and 6-phosphogluconate dehydrogenase increased 200 and $150 \%$, respectively, during the first 3 days in culture in the absence of added NGF, while tyrosine hydroxylase decreased slightly but significantly (Fig. 1). Addition of NGF to the culture medium increased the activity of tyrosine hydroxylase and at $200 \mathrm{nM}$ elevated the activity of this enzyme above control. In contrast, activities of the two oxidative enzymes of the pentose phosphate pathway were not affected by the addition of NGF to the culture medium.

The larger increases in activities of the two oxidative enzymes noted in vitro compared to changes observed in axotomized ganglia in vivo (Table II) may be explained, in part, by the influence of decentralization. Removal of presynaptic inputs to the ganglia by decentralization results in a significant enhancement of the induction of 6-phosphogluconate dehydrogenase produced by axotomy (Sinicropi et al., 1979). Decentralization alone has no effect on the activities of these enzymes, protein content, wet weight, or muscarinic binding in the ganglia (Burt, 1978; Sinicropi et al., 1979).

Localization of enzyme activities in vitro. Both oxidative enzymes were found to be localized mainly in the neurons of the explants maintained in vitro for 3 days. Figure 2 shows that deposition of reduced nitroblue tetrazolium resulting from glucose-6-phosphate dehydrogenase activity occurs mainly over nerve cell bodies with
TABLE III

The effect of NGF on protein content of explants after 3 days in vitro

Values are the mean \pm SEM of the number of paired samples shown in parentheses. Explants taken from the same ganglia as those cultured under various conditions served as matched controls. Protein content of pooled (4) explant homogenates were compared. The average micrograms of protein per explant was $13.5 \pm 0.9(9)$ in the control group.

\begin{tabular}{lr}
\hline \multicolumn{1}{c}{ NGF Concentration } & \multicolumn{1}{c}{ Protein } \\
\hline & \% of control \\
None added & $87.1 \pm 11.7(4)$ \\
$<10 \mathrm{nM}$ & $92.0 \pm 6.8(11)$ \\
$>10 \mathrm{nM}$ & $97.3 \pm 9.5(6)$ \\
\hline
\end{tabular}

much less staining of neuropil. Similar results were obtained for 6-phosphogluconate dehydrogenase.

Effects of glucocorticoids on muscarinic receptor and enzyme activities in vitro. It is known that NGF treatment elevates plasma glucocorticoids 7 - to 8-fold in rats (Otten et al., 1979) and that glucocorticoids enhance the induction of tyrosine hydroxylase in rat superior cervical ganglia in organ culture (Otten and Thoenen, 1977). Thus, we examined the effects of these steroids on enzyme activities and muscarinic binding in explants maintained 3 days in culture.

Addition of corticosterone to the culture medium, at a concentration similar to that in plasma of NGF-treated rats $(0.57 \mu \mathrm{M})$, did not prevent the induction of the two oxidative enzymes; i.e., activities were not significantly different from those noted in the presence of NGF alone. Activities of glucose-6-phosphate dehydrogenase in ganglion explants maintained in the presence of cortisone, NGF (200 nM) plus cortisone, or NGF alone were $4.33 \pm$ $0.93,5.81 \pm 1.23$, and $4.41 \pm 0.60 \mu \mathrm{mol} / \mathrm{mg}$ of protein/ $\mathrm{hr}$, respectively. Values for 6-phosphogluconate dehydrogenase in the three groups were $2.66 \pm 0.21,3.67 \pm 0.48$, and $3.43 \pm 0.50 \mu \mathrm{mol} / \mathrm{mg}$ of protein $/ \mathrm{hr}$, respectively. Addition of cortisol $(1.6 \mu \mathrm{M})$, equivalent to 10 times the biological activity of corticosterone in plasma of NGFtreated rats, also failed to alter the induction of the oxidative enzyme in explants maintained in the NGFcontaining medium. The specific binding of $N-\left[{ }^{3} \mathrm{H}\right]$ methylscopolamine, which remains constant after 3 days in culture in the presence of $200 \mathrm{nM}$ NGF, was also unaffected by the addition of the pharmacologic dose of cortisol.

\section{Discussion}

Changes noted in the rat superior cervical ganglion after 6-hydroxydopamine treatment closely resemble those seen after axotomy (Harkonen and Kauffman, 1974; Sinicropi et al., 1979). Although NGF is known to affect a number of biochemical properties of the nerve cell body after treatment with 6-hydroxydopamine, NGF does not prevent the destruction of the nerve terminals that occurs after administration of the drug (Levi-Mon-

assays of fresh explants were not significantly different from control values in assays of whole ganglia. The average activity of tyrosine hydroxylase in ganglia of saline-injected rats was 37.9 $\pm 1.5(7) \mathrm{nmol} / \mathrm{mg}$ of protein $/ \mathrm{hr}$. Statistical differences for $\mathrm{N}-\left[{ }^{3} \mathrm{H}\right]$ methylscopolamine $\left(\left[\mathrm{H}^{3}\right]\right.$ $N M S)$ and tyrosine hydroxylase from control values are indicated by asterisks: $*, p<0.05 ; * *$, $p<0.01$. 

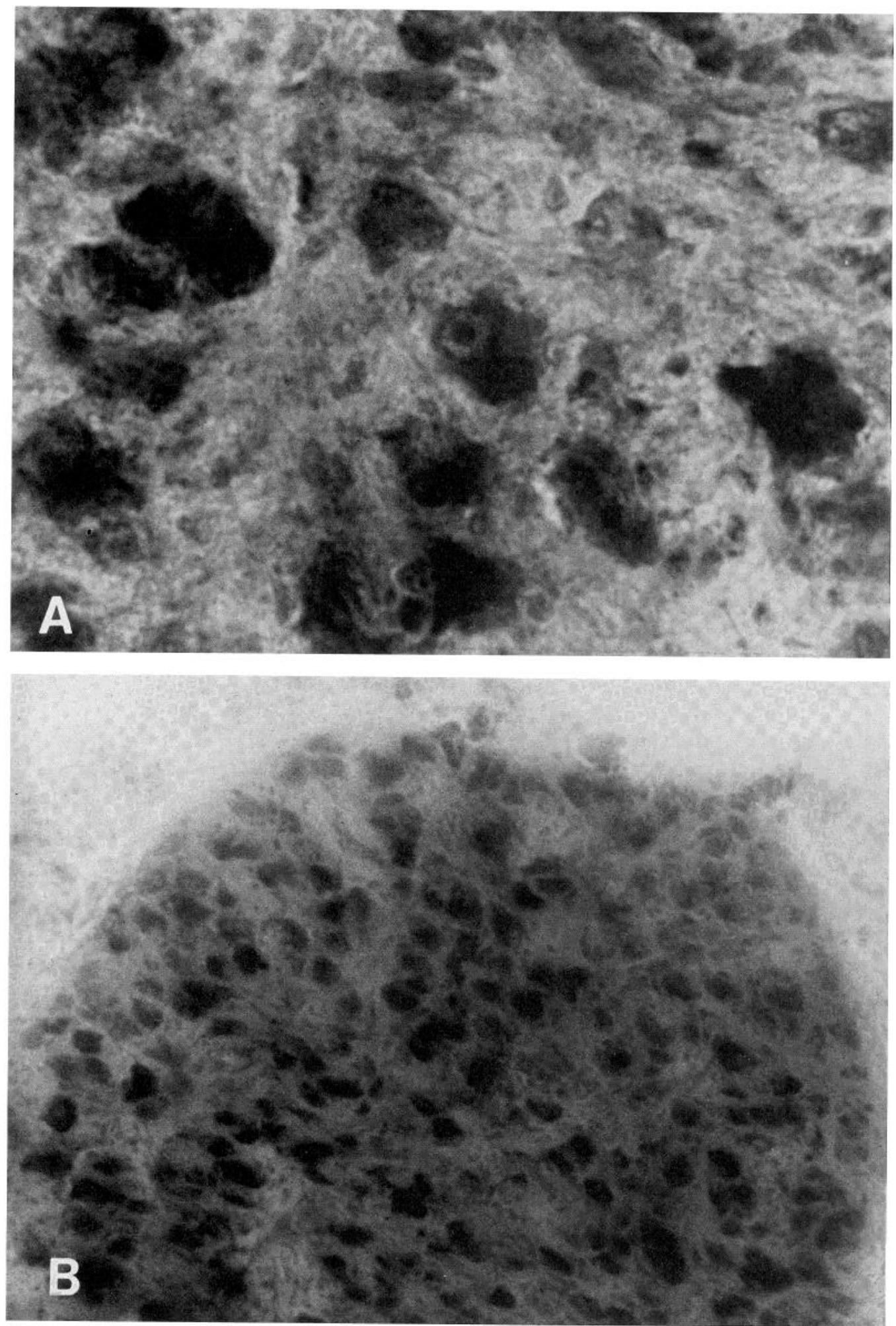

Figure 2. Histochemical localization of glucose-6-phosphate dehydrogenase in explants of the superior cervical ganglion after 3 days in culture. Ganglion explants were maintained in medium containing $200 \mathrm{nM}$ NGF. Note the relative lack of extraneuronal deposition of reduced tetrazolium. Magnification: $A, \times 130 ; B, \times 520$.

talcini et al., 1975). Destruction of nerve terminals by the drug is associated with a significant decrease in the retrograde transport of NGF to the superior cervical ganglion (Johnson et al., 1979). This may occur with $\mathrm{NGF}$ as well as other macromolecules and is apparently dependent on the loss of specific binding sites in nerve endings that are necessary for their uptake and transport (Dumas et al., 1979). The finding that decreases in $N$ methylscopolamine binding that occur in vivo after exposure to 6 -hydroxydopamine were markedly attenuated 
by the administration of NGF suggested that these changes may be mediated by a loss of NGF supplied to the ganglion nerve cell bodies. The results of our studies in vitro give further support to this hypothesis.

Changes in muscarinic binding in the tissue elicited by NGF may involve interaction of NGF with more than a single class of receptors. Dumas et al. (1979) suggest a limited number of NGF receptors of two affinities at adrenergic nerve terminals in vivo. The work of Sutter et al. (1979), Olender and Stach (1980), and Landreth and Shooter (1980) on chick sympathetic and sensory neurons and pheochromocytoma cells in culture demonstrated that receptors for NGF have both high and low affinities for this peptide with dissociation constants on the order of $10 \mathrm{pm}$ and $1 \mathrm{nM}$. Recently, Claude et al. (1982) described a single class of NGF receptors in dissociated neonatal rat sympathetic cell cultures. However, a second higher affinity class of receptors could not be ruled out. In our experiments in vitro, $N-\left[{ }^{3} \mathrm{H}\right]$ methylscopolamine binding in the explants was only maintained in the presence of high concentrations of NGF, i.e., 20 or $200 \mathrm{nM}$. Good neurite outgrowth from the explants is achieved at 50 to $200 \mathrm{pM}$ NGF. Thus, concentrations of NGF required for neurite outgrowth from the explants are considerably lower than concentrations needed to maintain muscarinic binding. Furthermore, tyrosine hydroxylase activity, which is known to increase in the whole ganglion cultured in the presence of high concentrations of NGF (Max et al., 1978), resembles muscarinic binding and was only elevated above control values with the highest concentration of NGF used, i.e., $200 \mathrm{nM}$. Earlier studies in adult mice also demonstrated that doses of NGF 3- to 4-fold greater than those used in our experiments over a 5 -day period increased the content of protein and tyrosine hydroxylase activity in the ganglion in vivo (Thoenen et al., 1974). These data suggest that maintenance of binding sites as well as tyrosine hydroxylase in sympathetic neurons requires that a significant proportion of low affinity NGF receptor sites be occupied.

Recent studies employing PC12 cells maintained in a serum-containing medium also indicated that NGF increased muscarinic binding in this cell line in vitro (Jumblatt and Tischler, 1982). These data, along with our finding that NGF affects muscarinic binding in adult differentiated autonomic tissue both in vivo and in vitro, demonstrate that amounts of cholinergic receptor binding can be regulated by a substance unrelated structurally to acetylcholine. Results presented above suggesting that NGF increases muscarinic receptor content differ from those reported recently for vasoactive intestinal polypeptide, which appears to increase the affinity and rate of association of muscarinic ligands with receptors in cat submandibular salivary gland (Lundberg et al., 1982). Other factors influencing muscarinic receptor binding include cholinergic agonists and nonspecific physiological changes such as thyroidectomy and cell death induced by various lesions (for review see Westlind et al., 1981).

The influence of NGF on muscarinic binding may also involve an indirect action of this peptide at presynaptic sites in the superior cervical ganglion. Although NGF is not transferred transynaptically after retrograde transport (Schwab and Thoenen, 1977), exogenous NGF can reverse the presynaptic degeneration seen following postsynaptic injury (Nja and Purves, 1978). Thoenen and Barde (1980) suggested that maintenance of the presynaptic terminal by NGF may occur via specific surface proteins on the postganglionic cells.

Although our earlier work had shown a coordinate and reciprocal action of surgical axotomy on muscarinic binding and 6-phosphogluconate dehydrogenase activity, the two oxidative enzymes of the pentose pathway examined failed to show a direct response to NGF in vitro. The results of the histochemical studies clearly indicate that the activities of these enzymes in the explants maintained in culture are primarily neuronal. The density of neurons as well as the pattern of staining is essentially the same as that observed in the intact ganglion in vivo (Harkonen and Kauffman, 1974). Thus, changes in enzyme activities and muscarinic binding observed in vitro probably do not reflect alterations in neuronal cell survival in the culture system used above. This conclusion is supported by previous findings indicating that the content of ATP (Dombrowski and Kauffman, 1981) and total DNA (Sinicropi et al., 1980) are essentially the same in explants of the ganglion maintained 7 days in vitro in the presence of $1 \mathrm{nM}$ NGF as that noted in fresh ganglia.

Whereas injection of NGF and 6-hydroxydopamine concomitantly eliminated the induction of the oxidative enzymes seen with 6 -hydroxydopamine alone in vivo, the addition of NGF to the medium or cultured explants did not reverse the increase in activities of these enzymes. Although NGF is known to elevate plasma glucocorticoids (Otten et al., 1979), changes in the oxidative enzymes do not appear to involve these steroids. Neither glucocorticoids alone nor glucocorticoids in combination with high concentrations of NGF prevented the induction of glucose-6-phosphate dehydrogenase or 6-phosphogluconate dehydrogenase after 3 days in culture. Thus, the action of NGF on the induction of the pentose phosphate pathway enzymes may involve participation of other hormones or trophic substances present only in vivo.

\section{References}

Birdsall, N. N. J., A. S. V. Burgen, and E. C. Hulme (1978) The binding of agonists to brain muscarinic receptors. Mol. Pharmacol. 14: 723-736.

Burt, D. R. (1978) Muscarinic receptor binding in rat sympathetic ganglion is unaffected by denervation. Brain Res. 143: 573-579.

Burton, L. E., W. H. Wilson, and E. M. Shooter (1978) Nerve growth factor in mouse saliva. J. Biol. Chem. 253: 7807-7812.

Claude, P., E. Hawrot, D. A. Dunis, and R. B. Campenot (1982) Binding, internalization, and retrograde transport of ${ }^{125} \mathrm{I}$ nerve growth factor in cultured rat sympathetic neurons. J. Neurosci. 2: 431-442.

Coyle, J. T. (1972) Tyrosine hydroxylase in rat brain-Cofactor requirements, regional and subcellular distribution. Biochem. Pharmacol. 21: 1935-1944.

Dombrowski, A., and F. C. Kauffman (1981) Growth of the adult rat superior cervical ganglion explants in serum-free media. Brain Res. 219: 407-421.

Dumas, M., M. E. Schwab, and H. Thoenen (1979) Retrograde axonal transport of specific macromolecules as a tool for characterizing nerve terminal membranes. J. Neurobiol. 10: 179-197. 
Halstead, D. C., and M. G. Larrabee (1972) Early effects of the antiserum to the nerve growth factor on metabolism and transmission in superior cervical ganglia of mice. In Immunosympathectomy, G. Steiner and E. Schonbaum, eds., pp. 221-236, Elsevier-North Holland Publishing Co., Amsterdam.

Harkonen, M. H., and F. C. Kauffman (1974) Metabolic alterations in the axotomized superior cervical ganglion of the rat. II. The pentose phosphate pathway. Brain Res. 65: 127139.

Hendry, I. A. (1975) The effect of axotomy on the development of the rat superior cervical ganglion. Brain Res. 90: 235-244.

Hendry, I. A. (1977) The effect of the retrograde axonal transport of nerve growth factor on the morphology of adrenergic neurons. Brain Res. 134: 213-223.

Hendry, I. A., R. Stach, and K. Herrup (1974a) Characteristics of the retrograde axonal transport system for nerve growth factor in the sympathetic nervous system. Brain Res. 82: $117-128$.

Hendry, I. A., K. Stoeckel, H. Thoenen, and L. L. Iverson (1974b) The retrograde axonal transport of nerve growth factor. Brain Res. 68: 103-121.

Johnson, E. M., R. Y. Andres, and R. A. Bradshaw (1978) Characterization of the retrograde transport of nerve growth factor (NGF) using high specific activity [ $\left.{ }^{125} \mathrm{I}\right]$ NGF. Brain Res. 150: 319-331.

Johnson, E. M., R. A. Macia, R. Y. Andres, and R. A. Bradshaw (1979) The effects of drugs which destroy the sympathetic nervous system on the retrograde transport of nerve growth factor. Brain Res. 171: 461-472.

Jumblatt, J. E., and A. S. Tischler (1982) Regulation of muscarinic ligand binding sites by nerve growth factor in $\mathrm{PC} 12$ cells. Nature 297: 152-154.

Landreth, G. E., and E. M. Shooter (1980) Nerve growth factor receptors on $\mathrm{PC} 12$ cells: Ligand induced conversion from low to high affinity sites. Proc. Natl. Acad. Sci. U. S. A. 77: 4751-4755.

Levi-Montalcini, R., and P. U. Angeletti (1968) Nerve growth factor. Physiol. Rev. 48: 534-569.

Levi-Montalcini, R., L. Aloe, E. Mugnaini, F. Oesch, and H. Thoenen (1975) Nerve growth factor induces volume increase and enhances tyrosine hydroxylase synthesis in chemically axotomized sympathetic ganglia of newborn mice. Proc. Natl. Acad. Sci. U. S. A. 72: 595-599.

Lundberg, O. J. M., B. Hedlund, and T. Bostfoi (1982) Vasoactive intestinal polypeptide enhances muscarinic ligand binding in cat submandibular salivary glands. Nature 295: 147-149.

Lowry, O. H., N. J. Rosebrough, A. L. Farr, and R. J. Randall (1951) Protein measurement with the Folin phenol reagent. J. Biol. Chem. 193: 265-275.

Matthews, M. R., and V. H. Nelson (1975) Detachment of structurally intact nerve endings from chromatolytic neurons of rat superior cervical ganglion during the depression of synaptic transmission induced by postganglionic axotomy. J. Physiol. (Lond.) 245: 91-135.

Max, S. R., H. Rohrer, U. Otten, and H. Thoenen (1978) Nerve growth factor-mediated induction of tyrosine hydroxylase in rat superior cervical ganglia in vitro. J. Biol. Chem. 253 : 8013-8015.
Nja, A., and D. Purves (1978) The effects of nerve growth factor and its antiserum on synapses in the superior cervical ganglion of the guinea pig. J. Physiol. (Lond.) 277: 53-75.

O'Farrell, P. H. (1975) High resolution two dimensional electrophoresis of proteins. J. Biol. Chem. 250: 4007-4027.

Olender, E. J., and R. W. Stach (1980) Sequestration of ${ }^{125} \mathrm{I}-$ labeled $\beta$ nerve growth factor by sympathetic neurons. J. Biol. Chem. 255: 9338-9343.

Otten, U., and H. Thoenen (1977) Effect of glucocorticoids on nerve growth factor-mediated enzyme induction in organ cultures of rat sympathetic ganglia: Enhanced response and reduced time requirement to initiated enzyme induction. $\mathrm{J}$. Neurochem. 29: 69-75.

Otten, U., J. B. Bauman, and J. Girard (1979) Stimulation of the pituitary-adrenocortical axis by nerve growth factor. $\mathrm{Na}$ ture (Lond.) 282: 413-415.

Palmatier, M. A., B. K. Hartman, and E. M. Johnson (1982) Endogenous nerve growth factor (NGF) is retrogradely transported in sympathetic neurons in vivo. Soc. Neurosci. Abstr. 8: 400 .

Purves, D. (1975) Functional and structural changes in mammalian sympathetic neurons following interruption of their axons. J. Physiol. (Lond.) 252: 429-463.

Purves, D., and A. Nja (1976) Effect on nerve growth factor on synaptic depression after axotomy. Nature (Lond.) 260: 535536.

Schwab, M. E., and H. Thoenen (1977) Selective transynaptic migration of tetanus toxin after retrograde axonal transport in peripheral sympathetic nerves: A comparison with nerve growth factor. Brain Res. 122: 459-475.

Singer, P. A., S. Mehler, and H. L. Fernandez (1982) Blockade of retrograde axonal transport delays the onset of metabolic and morphologic changes induced by axotomy. J. Neurosci. 2: 1299-1306.

Sinicropi, D. V., F. C. Kauffman, and D. R. Burt (1979) Axotomy in rat sympathetic ganglia: Reciprocal effects on muscarinic receptor binding and 6-phosphogluconate dehydrogenase activity. Brain Res. 161: 560-565.

Sinicropi, D. V., A. Dombrowski, C. W. Montgomery, R. K. Evans, and F. C. Kauffman (1980) Maintenance of the adult rat superior cervical ganglion in vitro: Comparison of organ and explant culture systems. J. Neurochem. 34: 1280-1287.

Sutter, A., R. J. Riopelle, R. M. Harris-Warrick, and E. M. Shooter (1979) Nerve growth factor receptors: Characterization of two distinct classes of binding sites on chick embryo sensory ganglion cells. J. Biol. Chem. 254: 5972-5982.

Thoenen, H., and Y. -A. Barde (1980) Physiology of nerve growth factor. Physiol. Rev. 60: 1284-1335.

Thoenen, H., I. A. Hendry, K. Stockel, U. Paravicini, and F. Oesch (1974) Regulation of enzyme synthesis by neuronal activity and by nerve growth factor. Wenner-Gren Cent. Int Symp. Ser. 8: 315-328.

Wamsley, J. K., M. A. Zarbin, N. J. M. Birdsall, and M. J. Kuhar (1980) Muscarinic cholinergic receptors: Autoradiographic localization of high and low affinity agonist binding sites. Brain Res. 200:1-12.

Westlind, A., M. Grynfarb, B. Hedlund, T. Bartfai, and K. Fuxe (1981) Muscarinic supersensitivity induced by septal lesion or chronic atropine treatment. Brain Res. 225: 131141. 